\title{
The Implementation of the Street Vendor Arrangement Policy on Jalan Diponegoro, Bandung
}

\author{
Rezky Afiahtul Barokah ${ }^{1}$, Sedarmayanti $^{2}$, Kurhayadi $^{3}$, Amirul Mustofa $^{4}$ \\ \{brezkyafiahtul@gmail.com¹, sedarmayanti@gmail.com², kurhayadi@gmail.com³ \\ ${ }^{1,3}$ STIA Bandung, Indonesia \\ ${ }^{2,4}$ Universitas. Dr. Soetomo Surabaya, Indonesia
}

\begin{abstract}
This study aims to analyze the implementation of the street vendor arrangement a policy on Jalan Diponegoro, Bandung, analyzing the challenges and efforts made by the Bandung City Government. This study uses aspects of Merilee S. Grindle as published variables, containing Policy Content (Policy Content) and Implementation Context (Implementation Environment). This study uses a case study research method using qualitative. The technique of data collection is done by collecting (observation), interviewing several SKPDs in Bandung City, PKL and community studies, as for the data verification techniques, the author uses source triangulation and technical triangulation. To analyze the data, the author seeks data collection, data reduction, data presentation and the end of the study draw conclusions. The results of the show that the implementation of the street vendors are still not optimal on Diponegoro Street in Bandung City policy arrangement. Constraints that occur are still low awareness of street vendors on existing legal regulations, weak supervision and added enforcement authorities, and relocation of street vendors selling goods that are not strategic and adequate, and do not have a relationship that is in accordance with the regulations regarding shop cars. Bandung City Government Efforts to overcome obstacles, namely making special regulations regarding shop cars, providing counseling, financial capital protection for street vendors, and team control to reach the regional level to the city level for judicial operations. In the discussion of this study, it was agreed that the implementation and arrangement of the street vendors could be done optimally, supervision and monitoring would improve, and the Bandung City Government should be implemented. Used as a place of business for street vendors.
\end{abstract}

Keywords: Policy implementation, arrangement, street-vendor

\section{Introduction}

Based on the explanation in the Law of the Republic of Indonesia Number 23 of 2014 concerning Regional Government, Article 18 paragraph (2) and (5) states that the Regional Government has the authority to regulate and manage government affairs according to the principle of autonomy and co-administration and given an autonomy as wide as broad. Giving the broadest possible autonomy to the regions is directed at accelerating the realization of community welfare through improved services, empowerment and community participation. In addition, through extensive autonomy, and in the strategic environment of globalization, the regions are expected to be able to increase competitiveness by paying attention to the principles of democracy, equity, justice, privilege, and specificity as well as the potential and diversity of regions within the 
Unitary Republic of Indonesia. The development of a region is essentially not merely building physical infrastructure, but must also be supported by economic development in order to create prosperity and prosperity for its people. Economic activity in people's lives aims to provide the needs needed by the community and to utilize the environment to improve the welfare of the community.

In line with this, the City of Bandung Government has set a vision of future development to establish/ Bandung as a city that is superior, comfortable and prosperous, with one of its mission to build a strong, advanced and equitable economy. This can be indicated by a commitment to achieving better economic development performance. The city of Bandung with a population of 2,440,717 people (source: Disdukcapil 2018) [1], has advantages compared to other cities in the country and has a special attraction for residents from outside the city of Bandung to do business and settle as a place to improve economic conditions. One of the potential developments of regional development in the city of Bandung is the informal sector business, such as street vendors. The existence of street vendors (PKL) is a dilemma for the government, besides being able to have a positive impact on economic growth, because street vendors are important because they can play a vital role in the business world to encourage economic growth, especially for the lower middle class. But on the other hand the existence of street vendors is often a problem for the government, especially can disrupt urban spatial planning or public space, because it is not uncommon for the street vendors to mostly sell over public spaces or use public facilities, which can disrupt public activities in carrying out their rights. The city of Bandung is a Metropolitan city which is the capital of West Java Province which is currently the center of community activities, even not only for the people of Bandung City itself but has become a tourist and business destination for people from other cities entering the city of Bandung, this is what makes the dynamics of rapid growth from all aspects of life both economic, socio-cultural and others. With a variety of attractions that exist in the city of Bandung both in the field of tourism, culinary and shopping centres so that Bandung becomes a city that is visited by many visitors to immigrants from outside the city of Bandung, so this is also the reason and the main cause of the problem of urbanization that is so high in the city of Bandung which consequently became a burden to the Bandung City Government, especially a burden relating to the issue of employment and their livelihoods.

A new phenomenon that is now becoming a problem for the Bandung city government is regarding street vendors who use transportation modes by using four wheels, namely street shop car dealers. The store's street vendors are one of the types of street vendors who use storefront media in the form of private vehicles. Most of the street vendors in the car sell their merchandise on the back of the vehicle, either minibusses or sedans. The increasing number and proliferation of street vendors (PKL) in Bandung is caused by many people making street vendors as an alternative choice for those who are not accommodated in the formal sector, especially coupled with the high unemployment rate so that becoming street vendors is the easiest, capital small and does not need to need any special skills. So that over time the number of street vendors will continue to grow and mushroom in every strategic location points especially places that are banned by the City Government. The existence of these street vendors increasing. In addition to Jalan Diponegoro, rows of PKL cars are also frequent spread in several locations including the Trunojoyo, Monju (Perjuangan Monument), Pahlawan road, Citarum road, Andir road, and Katamso road. 
The impact of the existence of shop mushrooms that are increasingly mushrooming can cause a negative influence on the order and beauty of the city, so that the beauty of the city begins to be disturbed by the emergence of shop car dealers who packed the sidewalks, shoulders, city parks and open spaces, even the impact can result against city traffic flows. The Bandung City Government applies the PKL Act which is based on the consideration that street vendors as part of the informal sector provide economic, sociological and noble values in the form of hard work, independence, harmony, and creativity to the people of Bandung (weighing verse (a) PERDA Number 4 of 2011) [2] Taking into account these contributions, the Bandung city government weighed the need to place street vendors as an integral part of planning, implementing government programs and policies relating to urban planning, especially those related to order, security, beauty and cleanliness of the city (weighing verse (b) Regional Regulation Number 4 of 2011). Bandung City Regulation No. 4 of 2011 regulates the location and place of business for street vendors which are divided into three zones namely the red zone, the yellow zone, and the green zone. Locations categorized as red zones are locations where street vendors are not permitted to trade at all. Included in the red zone are areas that are near or are places of worship, hospitals, military complexes, national roads, provincial roads, and 7 regions that have been determined in legislation.

The regulation was then supplemented by two Regulations of the Mayor (Perwal) of Bandung namely Number 888 of 2012 and No. 571 of 2014 as an implementation guide (operational guidelines). Perwal No. 571 of 2014 renewed Regulation No. 888 of 2012 in the determination of the location of the red, yellow and green zones, as well as regulating administrative sanctions against street vendors and buyers.

In an effort to build a clean, orderly and beautiful city, the Bandung City Government often arranges in all corners of the city, especially in terms of the arrangement of street vendors (street vendors) which are often considered still counterproductive. The Bandung City Government still has difficulties in structuring and controlling by relocating street vendors in places that have been provided by the City Government. In implementing the policy of relocating the street vendors, it is often faced with the incompatibility of expectations from the street vendors themselves on the relocation sites that have been provided. From several locations, there is a shop car dealer, which is the object of research in this study, are car dealers, shops on Diponegoro Street, Bandung City. This is because the majority of the row of car dealers shop peddling their merchandise on the Diponegoro street location in Bandung City. As seen in the table below:

Table 1. Condition of PKL Car Shop on Jalan Diponegoro, Bandung City

\begin{tabular}{clc}
\hline No. & Types of Merchandise & Number of Merchandise \\
\hline 1 & Shoes & 29 \\
2 & Jacket & 11 \\
3 & Pants & 4 \\
4 & Clothes & 16 \\
5 & Bag Traders & 2 \\
6 & Children's clothing & 6 \\
7 & Pillow & 1 \\
8 & Blanket & 1 \\
\hline \multicolumn{2}{r}{ Total }
\end{tabular}


Based on table 1.1 above, traders Based on table 1.1 above, the street vendor car shops on Diponegoro Street are dominated by footwear traders, amounting to 20 traders. Where these conditions have actually violated the rules issued by the City of Bandung government, namely violating Perda Number 11 of 2005 and Perda No. 4 of 2011 [2] concerning the arrangement and Development of Street Vendors, this is because traders sell not at their proper place. Street vendors sell on the shoulder of the road, causing congestion both for pedestrians and motorists, as well as disturbing the beauty of the road, and the Diponegoro road area includes the red zoning area, where street vendors are not allowed to sell. The existence of shop car dealers who usually sell along the streets of Diponegoro in Bandung City has been disciplined by related officials, namely the Bandung City Transportation Agency, Satpol PP, Bandung City Police, and the regional apparatus. Even though control has been carried out, the existence of shop car dealers still shows its existence to sell in that location. Control is carried out by cracking down on various violations of the shop car dealers who were found parking their vehicles on the Diponegoro road. Based on the observation of the author, the implementation of the Bandung City Regional Regulation No. 04 of 2011 [2] concerning the Arrangement and Development of Street Vendors (PKL), which was followed up with Mayor Regulation Number 571 of 2014 concerning Implementation Guidelines for Bandung City Regulation Number 04 of 2011 concerning Trader Arrangement and Development Street Vendors (PKL), it is still not optimal. This can be seen from several violations that have been violated by the Street Vendors in the car. From some of these violations are phenomena that become a problem about the implementation of the policy of structuring street vendor Mobil Toko on Jalan Diponegoro, Bandung City. These phenomena include:

a. The low legal awareness of the shop car street vendors or the non-compliance of the car dealers against existing regulations, especially the prohibition on selling in locations that are prohibited from selling, especially in the red zone. And this shop car street vendor violation looks like in Table 2.

Table 2. Number of street shop car dealers who break in the area of Jalan Diponegoro in Bandung Period

\begin{tabular}{lllll}
\hline $\begin{array}{l}\text { No } \\
.\end{array}$ Month & Ordered amount & Perda violated & Types of Violations \\
\hline 1 & January & 11 Offender rs & $\begin{array}{l}\text { Bandung City Regulation No. 11 of } \\
\text { 2005 concerning the Implementation } \\
\text { of Order, Cleanliness and Beauty } \\
\text { (K3) }\end{array}$ & $\begin{array}{l}\text { Selling in a place that } \\
\text { is prohibited }\end{array}$ \\
& February & 14 violators & $\begin{array}{l}\text { Bandung City Regulation No. 11 of } \\
\text { 2005 concerning the Implementation } \\
\text { of Order, Cleanliness and Beauty (K3) }\end{array}$ & $\begin{array}{l}\text { Selling in a place } \\
\text { that is prohibited }\end{array}$ \\
\hline
\end{tabular}

Source: Bandung Satpol PP 2017

Based on table 2 above, there are still many violations committed by street vendors driving mainly in the Jalan Diponegoro area for 2 (two) months, from January to February 2017, and this is seen from the table above in January there are 11 Offenders who sell in banned places, and in February there were 14 offenders who sold in prohibited places. 
b. Shop Car Street vendors have violated Law Number 22 of 2009 concerning Road Traffic and Transportation. In Law, it is emphasized that no other function of the road for traffic should interfere. However, with the conditions in the field that the Shop Car Street Vendors still sell their wares on the shoulder of the road.

c. Based on the type, Shop Car Street vendors have committed violations including misuse of vehicle designation. Where the vehicle used is a private vehicle. As seen in the table below:

Table 3. Vehicle Types Car Shop Street Vendors

\begin{tabular}{llll}
\hline No. & Transportation type & Vehicle Type & Number of vehicles \\
\hline 1 & Private vehicle & Gran Max & 15 units \\
2 & & Daihatsu Xenia & 6 units \\
3 & Toyota Avanza & 5 units \\
4 & Car Kijang (Carry) & 10 units \\
5 & Capsule Kijang & 6 units \\
6 & Daihatsu Zebra & 10 units \\
& Espass & 2 units \\
7 & Daihatsu Ayla & 1 unit \\
8 & KIA car & 55 units \\
\hline Total & &
\end{tabular}

Based on table 3 above, Street Vendors Car shops on the Diponegoro road are dominated by types of private vehicles with 15 types of Gran Max vehicles, because the Gran Max type of vehicle can accommodate a considerable amount of goods so that street vendors are easy to arrange their merchandise as a shop window selling. This condition actually violates the rules issued by the Bandung City government. Many passenger vehicles are converted into goods vehicles. While many goods vehicles were found to be incompatible with the administrative requirements to KIR unlicensed administration. This is because the type of vehicle used is not to be used properly. In this regard, the Bandung City Government is still reviewing operational regulations regarding shop car dealers so that the existence of the creative industry develops without regulations being violated.

Based on the description above, the research, the author argues that this problem insurgent is studied, the results of which are arranged in a Thesis entitled: "Implementation of Street Vendor Arrangement Policy (Case Study of Shop Car Dealers (Moko) on Jalan Diponegoro, Bandung)". Research purposes

The purpose of this study is to:

a. To obtain an understanding of the implementation of the street vendor arrangement policy (a case study of moko traders on Diponegoro Street, Bandung City).

b. To analyze the inhibiting factors in the Implementation of the street vendor arrangement policy (a case study of moko traders on Diponegoro Street in Bandung City).

c. To analyze the efforts that must be made in overcoming obstacles in the implementation of the street vendor arrangement policy (a case study of moko traders on Diponegoro street in Bandung City). 


\section{Theoretical Review}

\subsection{Policy Implementation}

Policy implementation is one part of public policy studies, this is because it can provide information to the government and the public in understanding a government program in question whether it is running as it should be. According to Ripley and Franklin [3] suggest that: "Implementation is what happens after the law is set which gives authority to programs, policies, benefits (benefits), or a type of tangible output (tangible output). Implementation includes actions by as an actor, especially the bureaucrats intended to make the program run ". In line with the opinion of Agustino [4] that: "Implementation is an implementation process for certain programs that have been formulated and stipulated in a rule to achieve a result (outcome) that has been set in the rule". Implementation is the implementation of basic policies. In this case, it can be in the form of an order law or important executive decisions or a decision of a judicial body. Content and context in it, in the form of identifying problems to be achieved through various ways to structure/regulate the implementation process. According to Mazmanian and Sabatier in Agustino [5] explained that: "Implementation of the policy is the implementation of basic policy decisions, usually in the form of laws, but can also be in the form of orders or important executive decisions or decisions of the judiciary. Typically, the decision identifies the problems that want to be addressed, explicitly states the goals and objectives to be achieved, and various ways to structure or regulate the implementation process". Based on the formulation of policy implementation as stated above, the implementation of the policy can be interpreted as the implementation of activities/ activities referring to the prepared guidelines so that the activities/activities that have been carried out can have an impact/impact on the community and can contribute to tackling problems that become the target of the program. Bressman and Wildansky in Agustino [5] stated that: "Implementation of the policy is a process of interaction between a set of goals and actions that are able to achieve the goal. Policy implementation is a continuous process from the policy formulation stage. At the formulation stage, the strategy and objectives of the policy are determined while at the stage of policy implementation, actions (actions) are held in achieving the desired goals ". Policy implementation is the most important key in the public policy process. Implementation of policy in principle is a way for a policy to achieve its objectives, no more and no less. This method is transformed through policy programs. An implementation that is related to processes, results, activities, and actions to make a major contribution to better conditions and situations.

\subsection{Model of Policy Implementation}

The model of implementing public policy is basically a simplifying abstraction from the phenomenon of the implementation of public policy in the real world. The following will be presented by several models of public policy implementation from policy experts, which among others are stated by:

a. Van Meter and Van Horn models Van Meter and Van Horn formulate 6 (six) variables that affect policy implementation, namely: (1) policy standards and objectives, (2) resources, (3) communication and use of coercion, (4) disposition of implementors, (5) characters implementing agency, and (6) social, economic and political conditions. Goals/targets and policy standards are crucial factors in the implementation process. 
b. Model Edward III. This model suggests that policy implementation is the stage of policymakers between policy formation and policy consequences for affected communities. The model of public policy implementation was put forward by Edward, in Dwiyanto Indiahono [6] pointing to four variables that play an important role in achieving successful implementation. These include (1) Communication, (2) Organizational structure, (3) Resources and (6) Disposition.

c. Merilee S. Model Grindle. Merile S. Approach Grindle is known as implementation as A Political and Administrative Process. The success of implementing a public policy can be measured by the process of achieving the final result (Outcomes), which is achieved or not the goal to be achieved. This was stated by Grindle, where the measurement of the success of the implementation of the policy can be seen from two things, namely:

1) Judging from the process, by questioning whether the implementation of the policy is in accordance with what is specified (design) with reference to the actions of its policies.

2) Is the policy goal achieved? This dimension is measured by looking at two factors:

a) Impact or effect on the community individually and in groups.

b) The rate of change that occurs and the acceptance of the target group and changes that occur.

Grindle states that the general process of implementation can be started when goals and objectives have been specified, programs have been designed and funds have been allocated to achieve the objectives. These three things are basic conditions for the execution of public policy.

According to Grindle [7] the success of policy implementation is determined by the Content of implementation and context of implementation. Content of implementation includes (1) interests affected by policy; (2) types of benefits; (3) the desired degree of change; (4) the position of policymakers; (5) who is implementing the program; and (6) resources deployed. The context of implementation includes (1) the power, interests, and strategies of the actors involved; (2) characteristics of institutions and authorities; and (3) responsiveness compliance.

Based on these arguments, in the author's view, to carry out abstractions in the research on the implementation of the store car street vendor arrangement policy at Jalan Diponegoro in Bandung City, the policy implementation theory proposed by Grindle is the most appropriate instrument. Considering that in this study, Grindle said that in general, the task of implementation is to form a linkage that facilitates policy objectives that can be realized as a result of government activity. Therefore, the task of implementation includes the formation of "a policy delivery system", where certain facilities are designed and implemented with the expectation of reaching the desired goals. Thus, a public policy which is a broad statement of goals, objectives, and means, is translated into programs of action intended to achieve the objectives stated in the policy. Where various programs can be developed to respond to the same policy objectives. More than that, these programs and activities are intended to bring about a change in the policy environment, a change can be interpreted as the impact of a program.

\section{Research Methods}

To understand and solve the problems that exist in the Implementation of the Street Vendor Arrangement Policy (Case Study of Shop Car Dealers (MOKO) on Jalan Diponegoro in Bandung City), a research method is needed which is basically a variety of procedures that embody patterns and procedures in implementation of something scientific research [8]. The method used in this 
research is qualitative research methods because phenomena that exist in natural situations (loci) are not yet clear. Direct and in-depth interaction with informants is needed, especially in the explanation of the implementation of the Shop Car Street Vendor arrangement policy and to gather information about the obstacles or obstacles faced in implementing the store car street vendor arrangement policy. The research model used in this qualitative research is using case studies. The reason for the researchers using the case study research model is because the case study is a research strategy in which the researcher carefully investigates a program, event, activity, process or group of individuals. Cases are limited by time, and activities and researchers gather complete information using various procedures for collecting data based on a predetermined time [9].

\subsection{Techniques and Data Collection}

\section{Instruments}

Data collection technique is one of the strategic steps in order to produce quality research. One of the peculiarities of qualitative research is that the main instrument of research is the figure of the researcher himself. The definition of an instrument or research tool is here precisely because it becomes everything from the entire research process [10]. In qualitative approach research, there are several methods that are often used to collect data and analyze with Observations (Observations), Interview Methods, Field Notes and Use of Documents.

\subsection{Data Verification Technique}

In qualitative research, data verification techniques are carried out by testing the validity and reliability of research instruments to obtain valid and reliable data. To test the data validity/validity of the data then using Triangulation referred to in this study is interpreted as checking data from various sources in various ways [11]. With triangulation, researchers can recheck their findings by comparing with various sources, techniques and time.

\subsection{Data Processing and Analysis Procedure}

After the data needed has been obtained in the process of collecting data, then data processing and analysis are carried out. Data analysis is the process of systematically searching for and compiling data obtained from interviews, field notes and documentation, by organizing data in categories, describing it into units, synthesizing, arranging into patterns, choosing which ones are important and will be studied, and make conclusions so that they are easily understood by themselves and others [11]. Furthermore, Miles and Huberman [12] stated that: "Activities in qualitative data analysis are carried out interactively and take place continuously until complete, so the data is saturated". The stages of data processing procedures in the study using interactive models, namely the initial steps of data collection, data reduction, data presentation and at the final stage the authors draw conclusions. 


\section{Result and discussion}

Implementation of the Street Vendor Arrangement Policy (Case Study of Shop Car Traders (MOKO) on Jalan Diponegoro, Bandung City).

\subsection{General description of street vendor car shop on Jalan Diponegoro, Bandung}

The location used by shop car street vendors as a place to sell is that they often use public places or public facilities that are intended for the public interest, such as sidewalks, road shoulders, city parks and roadside as a place of choice for traders. five to be used as a trading location for street vendors. The meaning of the location for trading street vendors is certain area boundaries in accordance with the utilization of the area which can be used to carry out trading activities for street vendors.

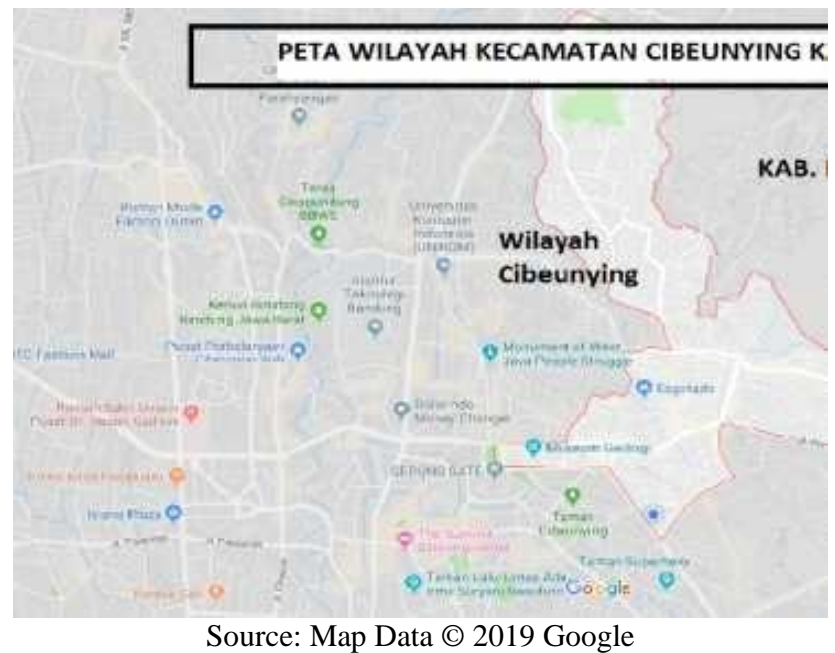

Fig. 1. Map of Locus Locations in Jalan Diponegoro, Cibeunying Kaler, Bandung

PKL Stores in Jalan Diponegoro, Bandung, are located in two locations, namely Jalan Sentot Alibasta and Jalan Kembar Pusdai, which are included in the Cibeunying Kaler District. There are a number of street vendors (PKL) mappings. Shop cars on Jalan Diponegoro in Bandung City are carried out on 60 shop car street vendors along Diponegoro Street, Bandung City. The characteristics of street vendors The shop on Diponegoro street in Bandung City is generally shown based on two aspects, namely the background aspect of being a street vendor and the business typology of a shop car street vendor. The two aspects are as follows:

\subsection{Background Aspect of Becoming a}

Street Vendor (PKL) Beginning to become a street vendor who has business activities in the city of Bandung, starting from the insistence of daily needs, both the needs for himself and his family. The main reason for being a street vendor is that it is not difficult to become a street 
vendor, because it does not require a lot of capital, even with small capital and even a small amount of money can begin to become a street vendor. After the researchers asked the street vendors, it turned out that the majority of street vendors in the city of Bandung had the main reason why they chose to become street vendors (PKL) among them, namely to fulfill their daily needs, not have jobs other than being street vendors because most were not have expertise, have low education, do not have large capital but the results are promising. There are also reasons for migrants to become street vendors in the city of Bandung, by choosing the city of Bandung as their destination, which according to them the city of Bandung is full of attractions as a center of tourism, culinary, shopping and education centers, making it a magnet for visitors to come to the city of Bandung. So according to the street vendors, this is a promising result with the reason that being a street vendor in the city of Bandung has a greater income compared to its place of origin, as well as a lot of strategic places in Bandung so that it is crowded with visitors. the street vendors as a place to sell.

Thus it can be interpreted that because there are no other jobs so that the job of being a street vendor is an option to fulfill daily needs. The government that functions as regulation as much as possible prevents actions that can be classified as acts of people's impoverishment such as the eviction and eviction of street vendors for the sake of order and beauty of the city, besides often causing turmoil and tendencies of conflict of interest. The government would need to think about how empowerment (empowerment), against the street vendors or find a wise solution (win-win). These efforts need to be taken in view of one of the functions of government is empowerment (empowerment) in addition to the service (service) and development (development). Local governments must provide opportunities for them, namely street vendors to be able to improve their business into an independent, advanced, orderly and legal business through empowerment.

Table 4. Team Organizational Structure Regulation Of Vocational School, Socialization Of Regulators No. 11/2005, Perda No 04/2011 And Perwal No.888 / 2012 (Administration / Storage Of Car Storage Shop In Jalan Diponegoro Kota Bandung)

\begin{tabular}{ll}
\hline Coach & $:$ 1.Camat of Cibeunying District Kaler \\
& 2.Kapolsekta Cibeunying Kaler \\
& 3.And Ramil Cibeunying Kaler \\
Director & $:$ Secretary of Cibeunying Kaler Sub-District \\
Person in charge & $:$ Field coordinator \\
Chairman & $:$ Kasi Trantib Kec. Cibeunying Kaler \\
Member & $:$ 1.Elements of the Department of Transportation \\
& 2.City PP Satpol Element \\
& 3. Koperindag and UKM ServiceElements \\
& 4.Cibeunying Kaler Police Element \\
& 5.Subdistrict and Sub-district Elements \\
& 6.The element of Community Protection \\
& 7.Elements of the Pillars of Citizens \\
\hline
\end{tabular}


Based on Table 4, it can be seen that the PKL Merchant Arrangement Team Shop Cars on Jalan Diponegoro in Bandung City were also formed by the Independence Team which was known by the Kasi Trantib Cibeunying Kaler Subdistrict and as the Trustees were Cibeunying Kaler Sub-District Head and Cibeunying Kaler Kapolsekta.

\subsection{Analysis of the Implementation of Street Vendor Car Shop Arrangement Policy on Jalan Diponegoro, Bandung City}

Based on the method used in this study as described in chapter 3, this study uses qualitative research methods with a case study approach. Thus the data analysis results of research in the field administratively began on March 29, 2019, on Jalan Diponegoro, Bandung, which was subsequently described in the form of a description and analysis based on the results of interviews. The data sources used in this study both primary data and secondary data presented in this study have been verified so that the data presented in this study already has validity and is in accordance with the current developments and situations that occur at the research locus. The process of collecting data as a basis for assessment, the author uses a semi-structured interview technique with several informants who are considered to understand and master various problems related to research.

In detail and comprehensively the study of data analysis results of the study is presented in the following description; Policy Contents (Content of policy) Implementation of policy in principle is a way for a policy to achieve its objectives. To implement public policy, there are two choices of steps available, namely directly implementing in the form of programs or through derivative policy formulations from the public policy. The success of implementation is basically determined by the clarity of the message conveyed by policymakers to the implementers determined by 3 factors: message content (message content), the form of the message itself, and the reputation of the communicator/policy maker. The policy content is a combination of the resources and credibility of the policy as a solution to a public problem. Therefore a policy will immediately be accepted and implemented by the implementing apparatus if the policy is accompanied by adequate resources and has credibility or is believed to be the best solution to the public problems that arise. The implementation process is influenced by several factors, which in turn can disrupt the changes between the policies adopted and the results given to the community. Grindle explained that the contents of the policy describe the interests affected (interest affected), types of benefits (type of benefits), desired degree of change (existence of change envisioned), position of decision making (site of decision making), program implementers (program implementers) and available resources(resources committed).

\subsection{Obstacles Faced in Implementing the Implementation of Street Vendor Arrangement Policies (A Case Study of Shop Car Traders on Jalan Diponegoro, Bandung City).}

In the implementation of the arrangement of the streetcar dealers in Diponegoro Street, Bandung, it turns out the implementation process in the field is still experiencing some obstacles faced by the Bandung City Government itself, especially in related SKPD services such as the Satpol PP Office, Cibeunying Kaler District Regional Office, and Bandung Transportation Department as the coordination team for the implementation of the arrangement. Some of the 
obstacles that occur in the process of implementing a shop car street vendor arrangement are as follows:

a. 1.Policy Information Factors and Low Legal Awareness. The policy regarding structuring and coaching carried out by the City Government of Bandung through the relevant department or SKPD as the structuring coordination team, apparently still experiencing obstacles faced in the field as not all of the street vendors can accept this government policy, so there are still many street vendors who are still stubborn selling in a place that is prohibited. So it is not uncommon for street vendors to often violate the order and also often use public places or facilities that can disturb the comfort of the general public. As well as the still low legal awareness of the vendors themselves against the rules of the applicable Regional Regulations.

b. 2.Factors of Human Resources (HR). The obstacles faced by everySKPDs that conducted arrangements to control the Satpol PP and the City of Bandung area, the Satpol PP and the territories were still experiencing shortages of personnel. Indeed, the number of Satpol PP and City of Bandung personnel can be fairly adequate, but when there are a control, arrangement and supervision event at the same time and place, there is usually a shortage of personnel. And there is still a lack of supervision carried out by Bandung City Perda enforcement officials.

c. 3.Means Factor. In the implementation of the arrangement of shop car street vendors carried out by the regional service, it is often faced with the constraints of the lack of adequate facilities for structuring and controlling so that the facilities used are not sufficient to carry out supervision so this can hamper the process of structuring the street vendors. in the city of Bandung especially in structuring the street vendor car shop on Diponegoro street.

d. 4.Economic factors of street vendors. There are also other factors which are obstacles in implementing this arrangement and guidance, namely the economic level of the street vendors themselves. Where the increasing mushrooming of street vendors selling due to economic factors. They are forced to sell in places that are prohibited by the government, because for them to buy or rent land that is official they are sometimes unable, therefore they end up selling in a makeshift place that is most important to get results to meet the needs of their families.

e. 5.Factors of Relocation Places. The lack of new relocation sites for street vendors in Bandung is a serious obstacle facing the city government. In addition, the problem of the relocation sites provided by the Bandung City Government turned out to often experience a discrepancy with the expectations of the street vendors for the relocation sites provided by the Government. Street vendors often demand to be given a strategic location. In general, street vendors are not willing to move to locations that are considered unprofitable for their business, street vendors reason that the relocation sites provided by the Bandung City Government are not strategic and far from the crowds, so the five street vendors refuse to be moved.

Efforts made by the government to implement the policy. Attempting to Provide a Relocation Site Efforts being made by the Bandung City Government in providing new locations or land for street vendors who have not yet obtained a relocation site. Looking for locations that will be used as new relocation sites, is a very important and urgent thing to be done by the Bandung City 
Government is to provide land for the street vendors who currently have so many numbers. So in order to provide legal protection for street vendors, the government itself has attempted to provide temporary land for shop car street vendors, such as the location on Jalan Diponegoro where it is being studied.

\section{Conclusion}

Based on the results of the research and discussion in chapter four, regarding the implementation of the policy of structuring street shop car dealers on Jalan Diponegoro, Bandung, a conclusion was obtained as follows:

a. From the policy content variable, the factors that influence the implementation performance of factor structuring policies that are relevant to the context of the implementation of shop car street vendor policies are the factors of interest that are affected by the policy, the degree of change desired, and the resources deployed. Whereas for the context variable implementation in compliance factor and responsiveness.

b. Constraints that arise in the implementation of structuring the store car street vendors conducted by the City Government of Bandung through its Satgasus Team, namely the low level of legal awareness of the street vendors themselves to existing rules, such as the Regional Regulation No. 11 of 2005 concerning Implementation of Order, cleanliness and beauty, Regional Regulation No. 04 of 2011 concerning the Arrangement and Development of Street Vendors, plus the weak supervision carried out by law enforcement officials themselves, this occurs because of the lack of quantity of Human Resources namely Satpol PP personnel, and regional train and lack of new relocation places for street vendors who are adequate and strategic, so there are still street vendors who do not want to be moved to the new relocation location because it is considered that the location is not profitable for their business. Moreover, the economic condition of the street vendors is alarming, forcing them to sell in a clear place is prohibited by the rules because the place is crowded and strategic, in order to meet the needs of their families. In an effort to implement this arrangement and guidance, it is still faced with a structuring procurement budget that is sometimes inadequate.

\section{References}

[1] "No Title." [Online]. Available: https://disdukcapil.bandung.go.id/.

[2] A. Ramadhan, "MODEL ZONANISASI PENATAAN PEDAGANG KAKI LIMA DI KOTA BANDUNG (PRESPEKTIF PERATURAN DAERAH KOTA BANDUNG NOMOR 4 TAHUN 2011 TENTANG PENATAAN DAN PEMBINAAN PEDAGANG KAKI LIMA)," Unnes Law J., vol. 4, no. 1, 2015.

[3] B. Winarno, "Kebijakan Publik: Teori," Proses dan Stud. Kasus, Jakarta Cent. Acad. Publ. Serv., 2014.

[4] L. Agustino, "Dasar-dasar kebijakan publik." Bandung: Alfabeta, 2008.

[5] L. Agustino, "Fundamentals of public policy," Bandung Alf. Mould. Thirdly, 2012.

[6] D. Indiahono, "Kebijakan publik berbasis dynamic policy analisys," Yogyakarta Gava Media, 2009. 
[7] M. S. Grindle, "Policy content and context in implementation," Polit. policy Implement. Third World, pp. 3-34, 1980.

[8] S. Syarifudin Hidayat, "Metodologi Penulisan." Bandung: CV: Mandar Maju, 2011.

[9] J. W. Creswell and V. L. P. Clark, Designing and conducting mixed methods research. Sage publications, 2017.

[10] L. J. Moleong, "Qualitative Research Methodology Revised Edition," Bandung PT Remaja Rosdakarya Offset Publ., 2013.

[11] Sugiyono, Qualitative, Qualitative and R \& D Research Methods. Bandung: CV. Alfabeta, 2014.

[12] H. Herdiansyah, "Qualitative research methodology," Jakarta: Salemba Humanika, 2010. 